\title{
Reform and Practice of Talent Cultivation Model of Food Engineering Based on "Excellence Program" in Perspective of Integration of Industry and Education
}

\author{
Chao $\mathrm{Li}^{1, \mathrm{a}}$ and Wang Weidong ${ }^{1, \mathrm{~b},{ }^{*}}$
}

\author{
School of Food (Biological) Engineering, Xuzhou Institute of Technology Xuzhou 221018, China \\ achaoge002@163.com, bwwd.123@163.com
}

Keywords: Integration of industry and education; Excellence program; Talent cultivation model of food engineering; Reform; Practice

\begin{abstract}
With the aim of cultivating students' ability of engineering practice, reform and practice of talent cultivation model of food engineering was conducted in Food Science and Engineering specialty of Xuzhou University of Technology, by formulating the core curriculum of food engineering, establishing the practice base of food engineering, implementing the special practice of food engineering and school-enterprise joint training by "double tutorial system". The results showed that the practical application effect was good by the test since 2006. It can be used as a reference for the talent cultivation model of food engineering of other undergraduate colleges.
\end{abstract}

\section{Introduction}

In order to meet the development needs of Xuzhou's 100 billion yuan industry of "processing of food and agricultural byproducts", the second batch of "Excellent Engineer Education and Training Program" was approved for the major of Food Science and Engineering on February 14, 2012. Based on this, a food engineering talent training mode with core courses of food engineering, practice bases, practice special and double tutorial system as the support points was established, which realized the deep conformity between talent training and enterprise needs, and achieved good application results.

\section{Food Engineering Talent Training Mode}

Formulating the "Core Course" of Food Engineering. Taking high and new technology of food engineering, principles and experiments of food engineering, machinery and equipment of food factory and design basis of food factory as core courses of food engineering, the students have mastered relevant engineering technology knowledge and basic professional skills of food manufacturing, and engineering basic quality of students is cultivated.

Establishing Food Engineering "Practice Bases". The food engineering practice base can be divided into two categories: school type and enterprise category. The former refers to four provincial practice bases on campus: The Provincial Experimental Teaching Center of Food and Bioengineering, The Food Resources Development and Quality and Safety Key Construction Laboratory in Jiangsu Province, The Provincial Engineering Laboratory of Biochip Agricultural Product Safety Testing Technology and The Research Center of Food Bioprocessing Engineering Technology in Jiangsu Province. The latter refers to five key practice bases outside the school and ten visiting practice bases. In particular, five key off-campus practice bases have been jointly constructed by school and large-scale enterprises with advanced technology and high industry influence, forming a project talent cultivation consortium based on "excellent program". Students are familiar with the advanced technology and equipment in the real engineering environment and the innovative process of modern food engineering technology from market orientation, quality design, technology research and development, production and manufacture to sales service. This improves students' comprehensive engineering ability to analyze and solve practical problems of enterprises and trains students' initial ability to carry out engineering innovation. 
Implementing the Food Engineering "Practice Special". Food engineering practice special refers to six major food engineering practice projects of the basic cognitive experiment, comprehensive design experiment, engineering basic training, professional comprehensive training and practice, practical innovation training and graduation design (thesis). Through the implementation of these specific practical projects, students have been trained in engineering practice, and internalization of knowledge, integration and engineering practice ability have been improved.

Using the "Double Tutorial System" School-Enterprise Joint Training. During the study period in enterprises, students are guided by "school instructors" and "business instructors". "School instructors" are teachers with strong engineering background, who follow and guide the students through the whole process. "Enterprise instructors" are the engineering technical and managerial personnel with rich practical experience in the enterprise employed by the school, responsible for the daily guidance and management of students' engineering practice in enterprises.

\section{Implementation Roadmap}

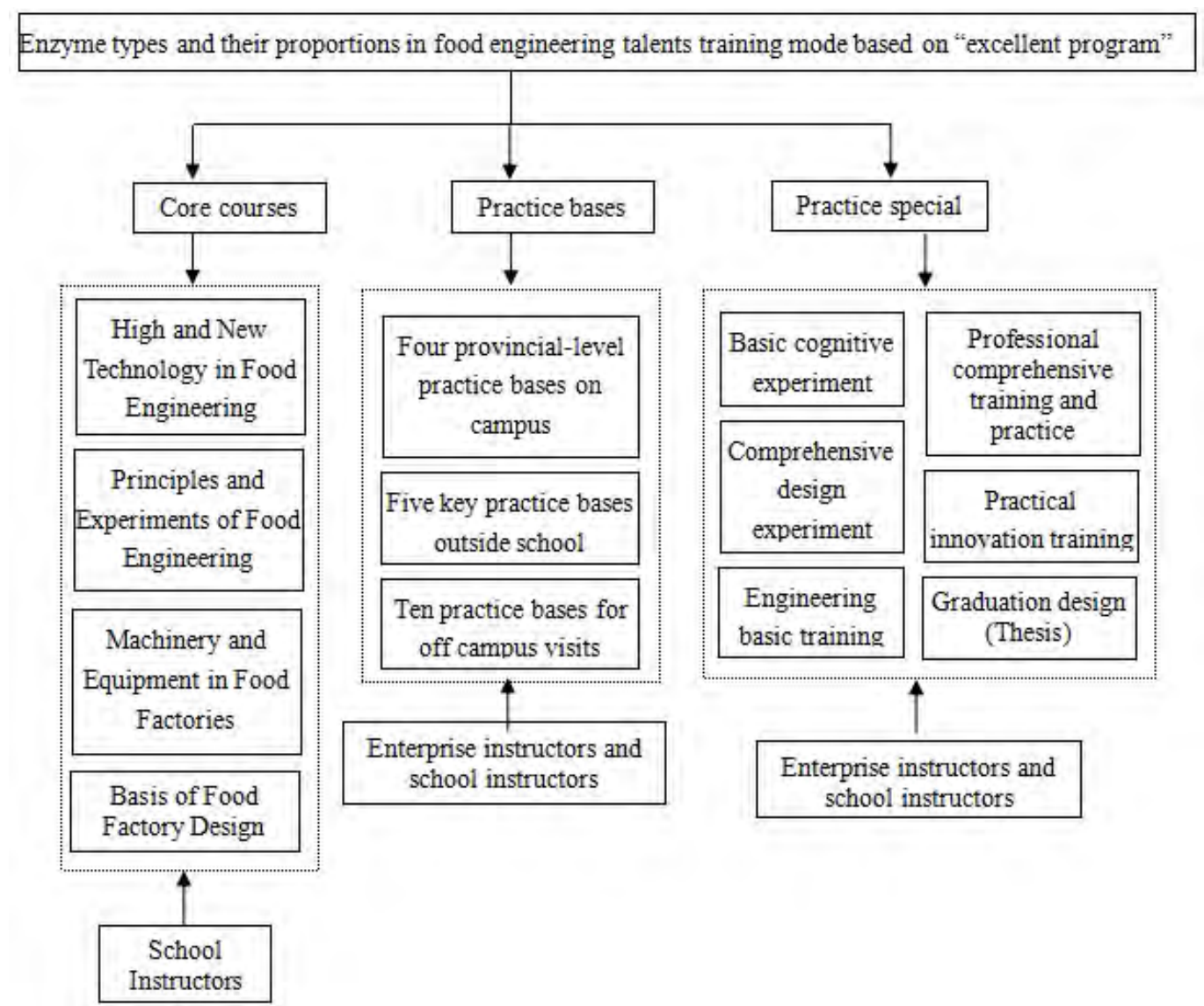

\section{Food Engineering Talent Training Teaching Program}

The Food Engineering Talent Training Scheme can be Formulated. According to the requirements of undergraduate engineering talents training in the "Excellent Engineer Education and Training Program" and the training objectives of applied talents in our university, the food industry enterprise experts (mainly including the backbone of enterprises and graduate representatives) were organized to conduct extensive investigation and demonstration on the food engineering talents training scheme. According to the development trend of food engineering technology, the requirements of food industry enterprises for engineering talents and the individualized development needs of students, a food engineering talent training scheme was 
formulated.

The Core Course System of Food Engineering can be Optimized. In accordance with the requirements of food engineering talents training scheme on knowledge, ability and quality structure, the food engineering high and new technology, food engineering principles and experiments, food plant machinery and equipment and food plant design foundation were set as core courses of food engineering. Through the reform of teaching mode and the construction of online open courses, the relevant theoretical teaching of food engineering was strengthened, the core curriculum system of food engineering was optimized, and the students received basic training in food engineering, thus forming a food engineering talent curriculum system that is organically combined with theoretical teaching system and relatively independent.

The Food Engineering Practice System can be Established. Based on the practice bases [four provincial practice bases on campus: The Provincial Experimental Teaching Center of Food and Bioengineering, The Food Resources Development and Quality and Safety Key Construction Laboratory in Jiangsu Province, The Provincial Engineering Laboratory of Biochip Agricultural Product Safety Testing Technology and The Research Center of Food Bioprocessing Engineering Technology in Jiangsu Province, five key practice bases outside the school and ten visiting practice bases outside the school] and six major food engineering practice projects(basic cognitive experiment, comprehensive design experiment, engineering basic training, professional comprehensive training and practice, practical innovation training and graduation design (thesis)), the food engineering practice system was established and optimized.

\section{Characteristics of Achievements}

From the perspective of the integration of industry and education, taking the cultivation of engineering ability and innovation ability as the main line, and combining the food engineering theory teaching with local economy and enterprise demand, this paper actively explores the food engineering talent training mode based on "excellent program".

The practice system of food engineering is established on the basis of practice base, practice special and double tutorial system. In particular, five key off-campus practice bases have been jointly constructed by school and large-scale enterprises with advanced technology and high industry influence, forming a project talent cultivation consortium based on "excellent program", enabling students to be trained in engineering practice.

Taking the engineering and technical problems to be solved urgently in the production and development of food enterprises as the leading factor, the targeted graduation design(thesis) topic selection is carried out. Under the guidance of the school and enterprise instructors, students can consult materials, design schemes and implement schemes by themselves, which exercises students' ability to analyze and solve practical problems, and students' engineering ability and innovation ability have been significantly improved.

\section{Application Effect of Achievements}

(1) 9 teaching reform projects related to project results: "Research on Talent Training Approach and Practice of "Excellent Program" in Applied Undergraduate Colleges", "Research on Training Methods of Outstanding Applied Talents in Food Specialty", "Exploration and Practice of Open Experimental Teaching Mode of Food Engineering Principle Experiment Based on "Excellent Program"', Teaching Reform of Graduation Design for Food Science and Engineering Specialty Based on "Excellent Program", "Research and Practice on the Training Mode of Characteristic Talents in the Specialty of Food Science and Engineering in New Applied Undergraduate Colleges", "Reform of Teaching Method of Principles of Food Engineering Based on the Cultivation of Engineering Practice Ability", etc., 12 papers on teaching and research: "Teaching Reform of Graduation Design in the Field of Food Science and Technology Based on the Program of Excellent Engineers Education Program"[1], "Practice Teaching Reform of Food Science and Engineering Specialty Based on the Integration of Industry and Education"[2], "Research on Reform of 
Integration of Production and Education in the Perspective of Grand Views of Application"[3], "Reform and Practice of Experiment Teaching of Food Engineering Principle for Educating and Training Outstanding Engineers"[4], “ Discussion on Teaching Reform of Food Engineering Practice Oriented to "Excellence Program"[5] and so on[6-16], 3 textbooks: Introduction and Improvement of the Chinese Version of AutoCAD2014, Food Machinery and Equipment of 12th Five-Year national planning textbook, and Principles of Food Engineering of 12th Five-Year national planning textbook, and 8 teaching awards: "Outstanding Student of the Ministry of Education", "The Third Prize of National College Life Science Micro Class Teaching Competition of Ministry of Education", "Second Prize of Jiangsu Province Undergraduate College Teaching Competition for Yong Teachers(Natural Science Use Subject Group)", "The Third Prize of Excellent Teaching Research Papers by the Teaching Research Committee of Teaching Management Research Association of Universities in Jiangsu" and so on are completed. In 2016, the application for certification of Food Science and Engineering specialty in our university has been accepted.

(2) According to the principles of students' voluntary and enterprise recognition, 20 people were selected from the food majors of 2009 and 2010 as subjects. Through the training of food engineering talents based on the "excellent program", 12 people passed for engineering master's degree, 11 were recruited in advance by five key practice bases outside the university, 14 people successfully found satisfactory jobs, and 3 people started their own businesses. The quality of students' graduation design has been greatly improved. They have been awarded the third prize of "Excellent Graduation Design (Thesis) of Jiangsu University" and the first prize of "Excellent Graduation Design (Thesis) of Xuzhou Institute of Engineering". The innovative ability of students' engineering practice has been greatly improved, and they have obtained one national college students' innovation and entrepreneurship training plan project, 5 provincial college students practical innovation training plan project, and 6 school-level practical innovation training plan projects for college students.

(3) During the training of food engineering talents based on the "excellent program" from the perspective of integration of industry and education, students participated in 6 national scientific research projects, 16 provincial and ministerial-level projects, 12 city department level projects, helped enterprises solve technological problems and updated 17 products for enterprises, participated in 45 academic papers, participated in 14 authorized national invention patents, and applied for 11 national invention patents.

\section{Acknowledgement}

Fund Project: The Funding Project of Construction Project of Brand Speciality of Universities in Jiangsu(PPZY2015B153 Food Science and Engineering)

\section{References}

[1] Yuee Sun: Teaching Reform of Graduation Design in the Field of Food Science and Technology Based on the Program of Excellent Engineers Education Program[J], Food Industry, 2014,35(12):211-214.

[2] Chao Li: Practice Teaching Reform of Food Science and Engineering Specialty Based on the Integration of Industry and Education[J], Farm Products Processing, 2016(12):79-80.

[3] Jinhui Hou, Enqi Liu and Weidong Wang: Research on Reform of Integration of Production and Education in the Perspective of Grand Views of Application[J], Farm Products Processing, 2016(12):84-85,88.

[4] Shirong Tang: Reform and Practice of Experiment Teaching of Food Engineering Principle for Educating and Training Outstanding Engineers[J], Science and Technology Vision, 2014(28):95-96.

[5] Enqi Liu, Shirong Tang, Yong Li, etc: Discussion on Teaching Reform of Food Engineering Practice Oriented to “Excellence Program”[J], Science \& Technology Vision, 2014(12):87. 
[6] Jie Qin, Hongling Liu, Enqi Liu, etc: Construction and Practice of Grading Open Experimental Teaching System in Local Colleges[J], Experimental Technology and Management, 2013(10):175-178.

[7] Shirong Tang: Construction and Practice of Grading Open Experimental Teaching System in Local Colleges[J], Journal of Anhui Agricultural Sciences, 2013(27):11232-11233.

[8] Kai Teng: Exploration on the Cultivation of Young Teachers' Engineering Quality in "Excellent Program"[J], Education Teaching Forum, 2015(31):30-31.

[9] Baojun Tu and Jingzhi Miao: Reform of Practical Teaching System of Food Specialty-A Brief Introduction to the Training Mode of Applied Talents in Food Specialty of Xuzhou Institute of Technology[J], Guangxi Journal of Light Industry, 2007,23(9):133-134.

[10] Yuee Sun: Characteristic Talents Training Mode in Food Science and Engineering Specialty[J], Academic Periodical of Farm Products Processing(Journal), 2014(10):81-83.

[11] Zhi Liang, Jie Ma and Zhengli Zhu: Analysis on Training Mode of Food Science and Engineering Talents Adapted to Regional Economic Development[J], China Education of Light Industry, 2009(1):28-30.

[12] Jianping Zhang, Enqi Liu, Shirong Tang, etc: Discussion on Teaching Reform of Experiment and Engineering Practice in Food Science and Engineering Specialty[J], Science and Technology Vision, 2013(26):128.

[13] Hui Song, Lihua Ma and Xuehong Chen: Reform and Practice on Professional Comprehensive Training Class of Food Major[J], Ningxia Journal of Agri.and Fores.Sci\&Tech, 2011,52(10):108-109.

[14] Lihua Ma: Exploration and Practice on Teaching Reform of "Food Technology Comprehensive Training"[J], China Education of Light Industry, 2006(4):64-67.

[15] Lihua Ma and Zhonghua Geng: Experiment Teaching of the Course of New Product Development in Food Specialty[J], Journal of Xuzhou Institute of Technology, 2006,21(12):104-105.

[16] Enqi Liu, Jianping Zhang, Shirong Tang, etc: Exploration and Practice on the Opening and Sharing Management Mode of Large-Scale Instruments[J], Research and Exploration in Laboratory, 2016,35(5):285-287.

[17] Yong Li: Introduction and Improvement of the Chinese Version of AutoCAD2014[M], Beijing: Posts and Telecom Press, 2014.

[18] Yong Li: Food Machinery and Equipment[M], Zhengzhou: Zhengzhou University Press, 2016.

[19] Tianli Yue: Principles of Food Engineering[M], Zhengzhou: Zhengzhou University Press, 2014. 